\title{
Proposed Corporate Performance Management System for XYZ City Government
}

\author{
Ayu Regita Cahyani Soleman and Muhammad Tresnadi Hikmat
}

\begin{abstract}
XYZ City Government has 3 Regionally-Owned Enterprises or Badan Usaha Milik Daerah (BUMD) that are managed independently to support the XYZ economic sector. In fact, one of the three BUMD management is bad, so that it makes the company go bankrupt because it produces losses. In addition, the Regional Original Revenue of XYZ City is very small when compared to other regions in West Java.

The purpose of this research is to propose a Performance Management System that can help to improve the performance of XYZ City Government. The improved performance can imply an indicator of success for the mayor's 5-year tenure and his deputy. The design of the Performance Management System was made by translating the vision and mission that was launched by the Mayor and his Deputy into a business strategy that was breakdown to each work unit (department).

This research uses the combined of Balance Scorecard and Integrated Performance Management System (IPMS) framework. This framework is used to assist organizations in achieving excellent performance seen from all aspects of the existing organization. Balance Scorecard Framework has 4 perspectives, such as Financial, Customer, Internal Process, and Learning \& Growth. The IPMS framework has 5 stages, Foundation, Background Information, Design, Implementation, and Maintenance and Update. IPMS has 3 perspectives, Organizational Output, Internal Process, and Resource Availability. The results of this study propose a Performance Management System with 62 Key Performance Indicators (KPI) derived from the company's vision, mission and strategy.
\end{abstract}

Index Terms - Performance Management System, Integrated Performance Management System.

\section{INTRODUCTION AND RESEARCH OBJECTIVES}

In a regional government system, there are regional heads (Mayor and Deputy Mayor) who lead. Refer to a local government authority, there is a Regional Development Plan that is in line with the National Development Planning System. In addition to the vision and mission launched by the Mayor and his Deputy, there is a document of Regional LongTerm Development Plan (RPJPD) program for 20 years, and a document of Regional Medium-Term Development Plan (RPJMD) program for 5 years, and a document of Local Government Work Plan (RKPD). Considering that the term of duty for a term of mayor and his deputy mayor is 5 years, the design of the Performance Management System that will be proposed refers to the RPJMD which is valid for 5 years from 2018-2023.

In regional autonomy, the head of the region is an element of regional governance that has the responsibility to achieve

Published on August 31, 2020.

Ayu Regita Cahyani Soleman, Bandung Institute of Technology, Indonesia.

(corresponding e-mail: ayu.regita@sbm-itb.ac.id) the vision, mission and goals for the welfare of the people [1]. People's welfare is achieved by carrying out development activities in accordance with the interests of the community. The implementation of regional autonomy and fiscal decentralization consists of three main missions [2], such as:

1. Improving the quality and quantity of public services and public welfare;

2. Creating efficiency and effectiveness in the management of regional resources; and

3. Empowering and creating space for the public (public) to participate in the development process.

RPJMD is:

1. Media to implement the promise of Mayor and Deputy Mayor who has been elected during the regional election

2. The instrument to measure the level of achievement of the performance of the Mayor and Deputy Mayor and Head of Regional Apparatus for five years

3. Control instruments for the Internal Supervisory Unit and Regional Development Planning Agency.

\section{A. Problem Statement}

XYZ City Government has 3 Regionally-Owned Enterprises or Badan Usaha Milik Daerah (BUMD) that are managed independently to support the XYZ economic sector. In fact, one of the three BUMD management is bad, so that it makes the company go bankrupt because it produces losses. In addition, the Regional Original Revenue of XYZ City is very small when compared to other regions in West Java.

\section{B. Research Objective}

The objective of this research is to provide the appropriate PMS and their KPIs for XYZ City Government using Balanced Scorecard and Integrated Performance Management System to support the vision and mission of elected Mayor and Deputy Mayor of XYZ City as described in RPJMD.

\section{RESEARCH METHODOLOGY}

The research method used in this study was qualitative, data were compressed from the results of an Forum Group Discussion attended by consultants and internal parties of XYZ City Government. In addition, to support this research, internal documents of the XYZ Government, literature studies include books, websites and journals are carried out.

Muhammad Tresnadi Hikmat, Bandung Institute of Technology, Indonesia (e-mail: muhammad.th@ ${ }^{\circledR}$ sbm-itb.ac.id) 


\section{Performance Management System}

Performance Management is about to learn what the organization requires to obtain or sustain its core competitiveness, and how the organization drives the employee to accomplish the targets, goals, and objectives. In nutshell, performance is all about changing the human behaviors in organization to gain desired results [3].

There are several frameworks of Performance Management System such as The Balanced Scorecard by Kaplan and Norton (1992), and Integrated Performance Managemeny System (IPMS) by Dermawan Wibisono (2006).

\section{BALANCED SCORECARD}

Balanced Scorecard is a strategic planning and management system tool to assist a firms or organization to measure their business performance using both financial and non-financial aspect [4].

1. Financial Perspective related to the financial performance of the organization.

2. Customer Perspective, the ability of organization treats the customer by providing the goods/service with excellent quality or to be the number one of delivering the value to the customer.

3. Internal Process Perspective relates to critical internal business processes that the organization runs from upstream to downstream which has a large impact on the satisfaction of the stakeholder.

4. Learning \& Growth Perspective, focused on the internal skills and capabilities that are required to support the value-creating internal processes for long-term success and continuous improvement of the organization.

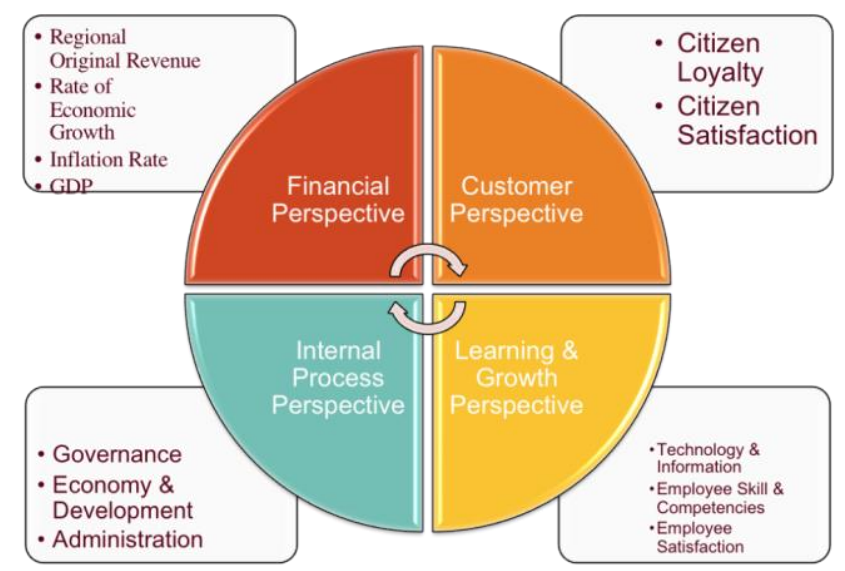

Fig. 1. BSC of XYZ City Government.

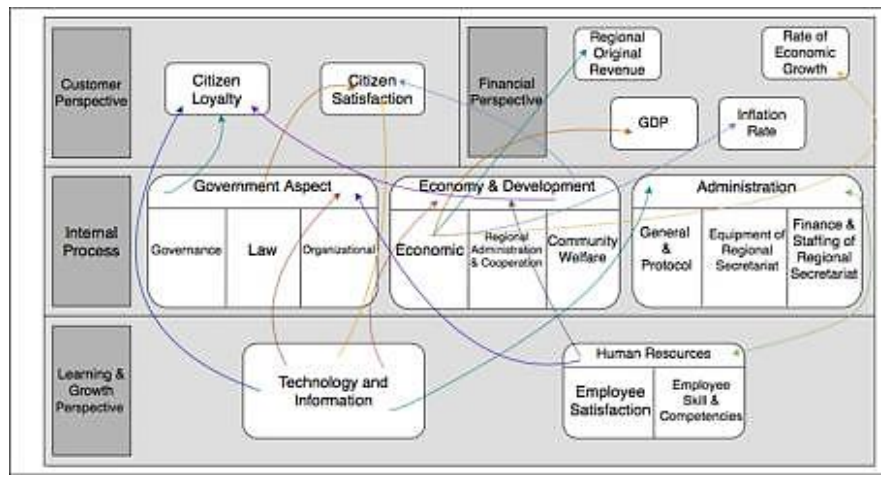

Fig. 2. Strategy Map of the BSC.

\section{INTEGRATEd PERFORMANCE MANAGEMENT SYSTEM}

Integrated Performance Management System (IPMS) was developed by Dermawan Wibisono, is one framework that can be used in measuring the performance of a company [5].

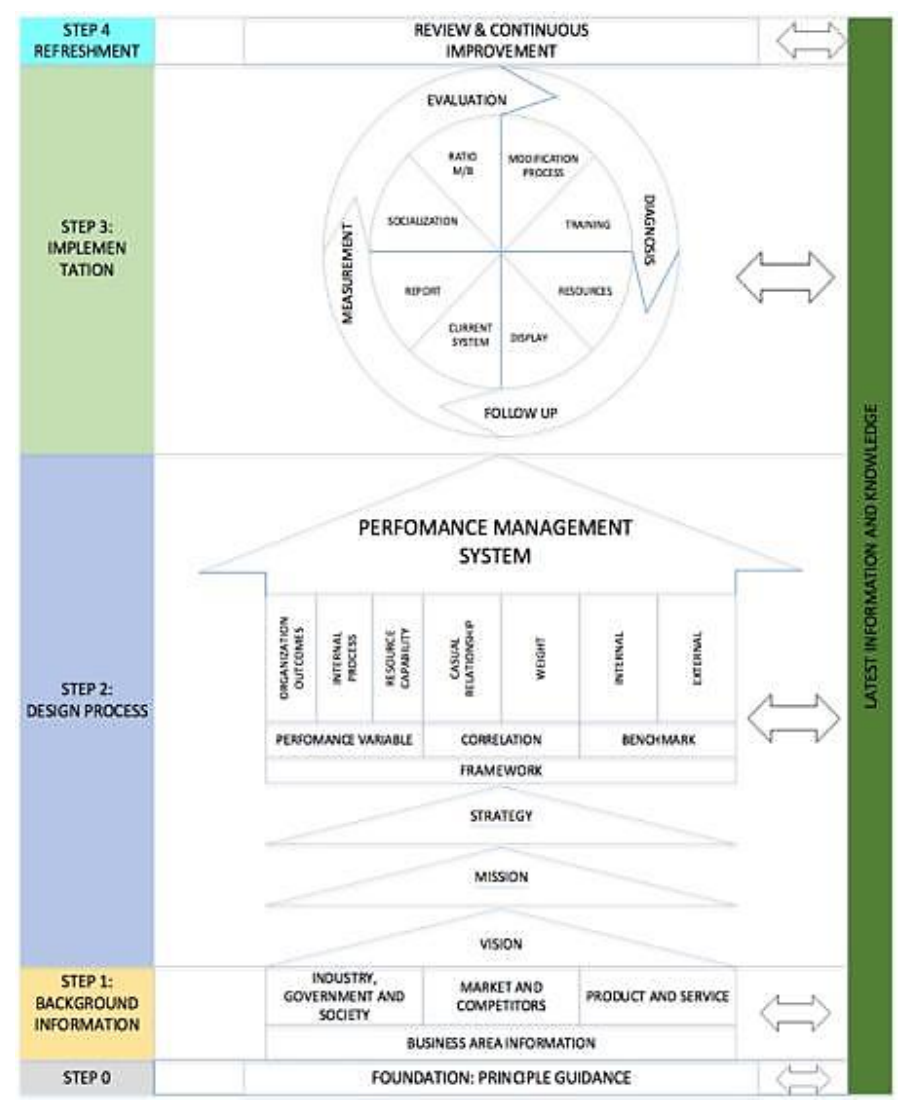

Fig. 3. IPMS Framework.

\section{A. Stage 0: Foundation}

In developing a good performance management system in an organization, there are 4 foundations as a guiding principle that must be considered (Partnership between XYZ Government's stakeholder, Empowerment of employees, Integrated Performance Improvement, and Independent Team. Besides, there are 5 good rules required to be applied such as easy to understand, long-term oriented, time-based, focus on sustainable development, and use quantitative approach.

\section{B. Stage 1: Background Information}

\section{Internal Factor Analysis}

Internal analysis conducted includes resources and value chain activity as a basis for the capabilities and competencies of birds in achieving competitive advantage [6]. In this research, internal factor analysis using Resource Based View. Resource-Based View (RBV) is a tool to assist an organization to create a sustainable competitive advantage by identifying a review of combination of special assets, resources (tangible and intangible), skills, capabilities. Tangible resources are physical assets, including in cash, vehicles, buildings, investments, manufacturing facilities, inventories, production equipment. There are two types of tangible resource, such as fixed and current. While the intangible resources are typically non-physical asset over the long-term and rooted deeply in organization history. Intangible assets are intellectual property that include in 
knowledge, patents, copyrights, company's brand, reputation, managerial capabilities, scientific capabilities, etc.

TABLE 1: TANGIBLE RESOURCE

\begin{tabular}{|l|l|}
\hline $\begin{array}{l}\text { Financial Resource } \begin{array}{l}\text { (Regional Revenues and } \\
\text { Expenditures Budget) }\end{array} \\
\text { Organizational Resource }\end{array}$ & $\begin{array}{l}\text { Organization's ability to get } \\
\text { loans/borrowing capacity } \\
\text { Organization's ability obtain/generate } \\
\text { funding from internal }\end{array}$ \\
\hline $\begin{array}{l}\text { Organization's report formalities and } \\
\text { formalities in planning, controlling and } \\
\text { coordinating. }\end{array}$ \\
\hline $\begin{array}{l}\text { Physical Resource } \\
\text { (Facilities) }\end{array}$ & $\begin{array}{l}\text { How strategic the office location and } \\
\text { how excellent the equipment/tools }\end{array}$ \\
\hline Technological Resource & $\begin{array}{l}\text { Stock technology such as patents, } \\
\text { copyrights, and trade secrets }\end{array}$ \\
\hline
\end{tabular}

TABLE 2: INTANGIBLE RESOURCE

\begin{tabular}{|c|c|}
\hline Human Resource & $\begin{array}{l}\text { Knowledge } \\
\text { Skills } \\
\text { Managerial Capability } \\
\text { Mutual trust } \\
\text { Collaborative Ability }\end{array}$ \\
\hline Innovation Resource & $\begin{array}{l}\text { Ideas } \\
\text { Scientific Ability } \\
\text { Capacity to Innovate }\end{array}$ \\
\hline Reputation Resource & $\begin{array}{l}\text { Reputation with community } \\
\text { Brand } \\
\text { Perception of service quality } \\
\text { Reputation with supplier } \\
\text { Efficient, effective, supportive, and } \\
\text { mutual benefit interaction and } \\
\text { relationship }\end{array}$ \\
\hline
\end{tabular}

TABLE 3: RBV TANGIBLE

\begin{tabular}{|c|c|c|c|c|c|c|}
\hline \multicolumn{2}{|c|}{ Resource } & Valuable & Rare & $\begin{array}{l}\text { Costly to } \\
\text { Imitate }\end{array}$ & $\begin{array}{c}\text { Non- } \\
\text { substitutable }\end{array}$ & $\begin{array}{l}\text { Competitive } \\
\text { Implications }\end{array}$ \\
\hline \multicolumn{7}{|c|}{ Tangible Resources } \\
\hline \multirow{2}{*}{$\begin{array}{l}\text { Financlal } \\
\text { Resource }\end{array}$} & $\begin{array}{l}\text { Organization's ablity to } \\
\text { get loansiburtowing } \\
\text { capacity }\end{array}$ & Yes & No & No & Yes & $\begin{array}{c}\text { Competitive } \\
\text { Parity }\end{array}$ \\
\hline & $\begin{array}{l}\text { Organization's ability } \\
\text { obtain/geserste fanding } \\
\text { from istermal }\end{array}$ & Yes & No & No & Yes & $\begin{array}{c}\text { Competitive } \\
\text { Parity }\end{array}$ \\
\hline $\begin{array}{l}\text { Organizational } \\
\text { Resource }\end{array}$ & $\begin{array}{l}\text { Organizativn's report } \\
\text { formalities and } \\
\text { formalities in planning. } \\
\text { controlling and } \\
\text { coordinating. }\end{array}$ & Yes & No & No & Yes & $\begin{array}{c}\text { Competitive } \\
\text { Parity }\end{array}$ \\
\hline \multirow{2}{*}{$\begin{array}{l}\text { Physical } \\
\text { Resource }\end{array}$} & $\begin{array}{c}\text { How strategic the office } \\
\text { location }\end{array}$ & Yes & No & No & Yes & $\begin{array}{l}\text { Competitive } \\
\text { Parity }\end{array}$ \\
\hline & $\begin{array}{l}\text { How excellent the } \\
\text { equipmentiools }\end{array}$ & Yes & No & No & No & $\begin{array}{c}\text { Competitive } \\
\text { Dissdvantage }\end{array}$ \\
\hline $\begin{array}{c}\text { Technotogieal } \\
\text { Resource }\end{array}$ & $\begin{array}{l}\text { Stock technology such as } \\
\text { patents, copyrights, and } \\
\text { trade secrets }\end{array}$ & Yes & No & Yes & Yes & $\begin{array}{l}\text { Temporary } \\
\text { Competitive } \\
\text { Advantage }\end{array}$ \\
\hline
\end{tabular}

\section{External Factor Analysis}

PESTLE (Political, Economic, Socio-cultural, Environmental, and Legal) Analysis is a framework for describing external environmental factors used to determine current environmental conditions that will affect consumers and products offered by companies [7].

Political. Collaboration carried out by the local government with the Ministry of Social Affairs to develop human resources in integrated social welfare programs, cooperation between the regional government, the district government of XYZ, and the city of Bandung. Collaboration related to program alignment and local development in terms of providing public services, optimizing the utilization of resources owned by each region.
TABLE 4: RBV INTANGIBLE

\begin{tabular}{|c|c|c|c|c|c|c|}
\hline \multicolumn{7}{|c|}{ Intangible Resource } \\
\hline \multirow{5}{*}{$\begin{array}{l}\text { Humun } \\
\text { Resource }\end{array}$} & Knowledge & Yes & Yes & Yes & Yes & $\begin{array}{l}\text { Sustainable } \\
\text { Competitive } \\
\text { Advantage }\end{array}$ \\
\hline & Skills & Yes & Yes & Yes & Yes & $\begin{array}{l}\text { Sustainable } \\
\text { Competitive } \\
\text { Advknate }\end{array}$ \\
\hline & Masagerial Capubility & Yes & Yes & No & Yes & $\begin{array}{l}\text { Temperary } \\
\text { Competitive } \\
\text { Advantage }\end{array}$ \\
\hline & Mutaal Trust & Yes & Yes & Yes & Yes & $\begin{array}{l}\text { Sastainable } \\
\text { Competitive } \\
\text { Adsvantage }\end{array}$ \\
\hline & Collaborative Ability & Yes & Yes & No & Yes & $\begin{array}{l}\text { Temporary } \\
\text { Competitive } \\
\text { Advantage }\end{array}$ \\
\hline \multirow{3}{*}{$\begin{array}{l}\text { Innovation } \\
\text { Resource }\end{array}$} & Ideas & Yes & Yes & No & Yes & $\begin{array}{l}\text { Tempotary } \\
\text { Competitive } \\
\text { Advantage }\end{array}$ \\
\hline & Scientific Ability & Yes & No & No & Yes & $\begin{array}{c}\text { Competitive } \\
\text { Parity }\end{array}$ \\
\hline & Capacity to innovate & Yes & No & No & Yes & $\begin{array}{c}\text { Competitive } \\
\text { Parily }\end{array}$ \\
\hline \multirow{5}{*}{$\begin{array}{l}\text { Reputation } \\
\text { Resource }\end{array}$} & $\begin{array}{l}\text { Reputation uith } \\
\text { community }\end{array}$ & Yes & Yes & Yes & Yes & $\begin{array}{l}\text { Sustainable } \\
\text { Competitive } \\
\text { Advanaage }\end{array}$ \\
\hline & Brand & Yes & Yes & Yes & Yes & $\begin{array}{l}\text { Sustninable } \\
\text { Competitive } \\
\text { Advantage }\end{array}$ \\
\hline & $\begin{array}{l}\text { Perceptian of service } \\
\text { quality }\end{array}$ & Yes & Yes & Yes & Yes & $\begin{array}{l}\text { Sustainable } \\
\text { Competitive } \\
\text { Advantage }\end{array}$ \\
\hline & Reputation with supplier & Yes & Yes & Yes & Yes & $\begin{array}{l}\text { Sustainable } \\
\text { Competitive } \\
\text { Advantage }\end{array}$ \\
\hline & $\begin{array}{l}\text { ESfrieient, effoctive, } \\
\text { suppontive, and mottual } \\
\text { benefit interaction and } \\
\text { relationship }\end{array}$ & Yes & Yes & Yes & Yes & $\begin{array}{l}\text { Sustainable } \\
\text { Competitive } \\
\text { Advantage }\end{array}$ \\
\hline
\end{tabular}

Economic. Not yet optimal efforts to reduce poverty carried out by the government, APD 2013-2017 tends to rely on balancing funds (funds from the Central Government specifically allocated to fulfil regional needs, for example, taxes, general allocation funds, special allocation funds) rather than regional income.

Sociocultural. The high crime rate is caused by the occurrence of social and economic inequality which is quite far. Although the unemployment rate decreases every year, there is a workforce that is not absorbed by employment. This is due to the relatively low quality of labor. Besides, collaboration is carried out by the regional government and the local BPJS to facilitate the registered community in relation to health insurance.

Technological. Limited understanding, utilization, and use of information and communication technology in each Regional Apparatus in the Regional Government. Besides, the industry in XYZ in general still uses relatively simple technology so that the products produced cannot compete in the global market. However, the Regional Government continues to strive to develop MSMEs through the use and fulfilment of existing business facilities and infrastructure.

Environmental. The local government cooperates with educational institutions related to the environment, natural resources, etc. Collaboration with IPB in order to maintain the declining agricultural land due to a shift in function. However, waste management in XYZ is still not optimal.

Legal. In running the entire system of government, the Regional Government refers to the central government system, provincial government, and district/city government. Legislation has been amended several times, most recently by 
Law Number 9 of 2015 which is the second amendment to Law Number 23 of 2014 about the Regional Government.

\section{SWOT Analysis}

SWOT Analysis is a tool of the overall evaluation of an organization's strengths, weaknesses, opportunities, and threats to control and monitor the external and internal circumstances [7].

\section{Strengths}

a. XYZ service sector has an advantage compared to other sectors. Service sector are the business fields that contribute the largest to Gross Regional Domestic Product.

b. The dominant ecosystem that owned by XYZ in almost every district are the healthy living space and water supply services.

c. Security in investing.

\section{Weaknesses}

a. XYZ's Original Revenue is small compared to other regions.

b. Perumda/BUMD (Regionally-Owned Enterprises) has poor internal management.

c. The construction of Pelita semi-modern market facility has not yet been completed.

d. XYZ has a large workforce and the quality of labor is still relatively low.

e. In the education sector, educators has a low quality and quantity.

f. Lack in traffic management.

g. Lack of strategic and representative street vendor (PKL) shelters locations.

h. Unequal physical development and urban infrastructure. The high level of slum.

i. Local Government, industrial businesses, and XYZ SMEs are less literate about technology, information, and communication

j. Uneven rapid growth in the regional population.

\section{Opportunities}

a. Continued improvement in economic conditions, both domestic and global becomes a consideration for the investor to invest.

b. Opportunities for the development of the tourism sector.

c. Develop a tourist object destination and creative culinary SMEs.

d. XYZ has considerable potential in the hotel sector and will have an impact on the development of the tourism sector.

e. Improving fisheries culture in the community.

\section{Threats}

a. XYZ is included in an area that has a high index of disaster-prone.

b. Declining in the agricultural land area due to the result of the shift of function to non-agricultural land.

c. The traffic jam that occurs is quite high

d. The high level of migration of district residents to XYZ City.

\section{TOWS Matrix}

TOWS matrix is the crucial completing tool to enhance the organization in identifying strategies systematically considering the relations between Strengths, Weakness, Opportunities, and Threats as in SWOT Analysis.
TABLE 5: TOWS MATRIX

\begin{tabular}{|c|c|}
\hline S-O & W-O \\
\hline $\begin{array}{l}\text { SO1O1 - Government expanding the business sectors in } \\
\text { the service sector to attract the investors. } \\
\text { S2O2 - Development of the tourism sector by utilizing } \\
\text { useful ecosystems and healthy living space that is owned } \\
\text { by other regions. } \\
\text { S3O3 - Attract and convince investors to be interested in } \\
\text { investing in SME attractions and creative culinary } \\
\text { considering that Sukaburod has a high level of security in } \\
\text { investing. } \\
\text { S12304 - Utilizing ecosystems and bealthy living space } \\
\text { to build hotels around tourist attractions and attract local } \\
\text { and foreign investors to take part in investments in the } \\
\text { development of the tourism. } \\
\text { S2S3OS - Carmpaigns for govermment programs to } \\
\text { consume fish to attract investors to utilize bealthy living } \\
\text { space and water supply services for fish farming } \\
\text { investment. }\end{array}$ & 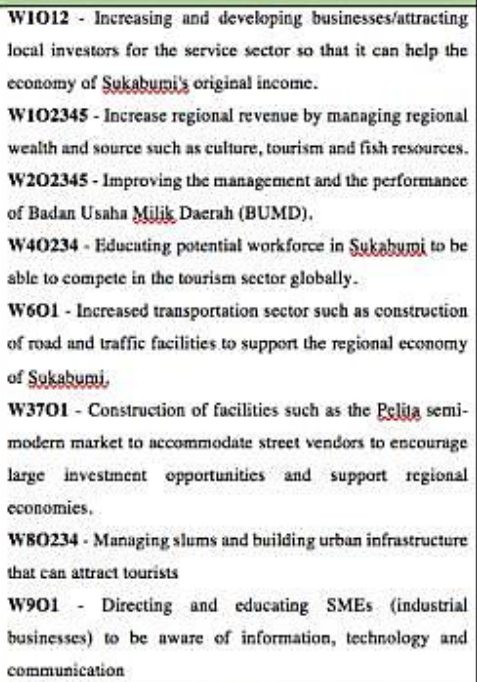 \\
\hline $\bar{S}$ & \\
\hline $\begin{array}{l}\text { S2T2 - Maintaining agricultural land that has changed its } \\
\text { function so that Sukaburol can still produce for food } \\
\text { availability. } \\
\text { S3T3 - Development of investment in the accommodation } \\
\text { and transportation sector to reduce traffic jam, } \\
\text { S1T4 - Expanding business sector in urban areas in } \\
\text { service fields in accordance with bigh levels of migration } \\
\text { for reasons of employment opportunitics. }\end{array}$ & 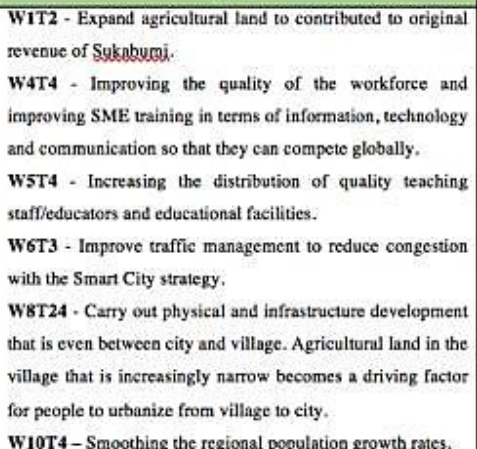 \\
\hline
\end{tabular}

\section{Stage 2: Design}

This stage consists of vision, mission, and strategy. After the vision, mission, and strategy under the RPJMD was declared by the head of the region, the framework of PMS is applied. There are 3 perspective in proposing the performance indicator in IPMS, i.e. Organizational Output, Internal Process, and Resource Capability.

TABLE 6: PERFORMANCE VARIABLE OF IPMS

\begin{tabular}{|c|c|}
\hline Perspective & Aspect \\
\hline \multirow{2}{*}{ Organizational Output } & Financial \\
\cline { 2 - 2 } Internal Process & Non-Financial \\
\cline { 2 - 2 } & Ecovernance \\
\cline { 2 - 2 } & Administration \\
\hline \multirow{4}{*}{ Resource Availability } & Human Resource Capability \\
\cline { 2 - 2 } & Technology Resource Capability \\
\cline { 2 - 2 } & Organizational Resource \\
& Capability \\
\hline
\end{tabular}

TABLE 7: CRITERIA OF GOOD VISION CHECKLIST

\begin{tabular}{|c|c|c|}
\hline Criteria & Yes & No \\
\hline Single sentence & $\checkmark$ & \\
\hline $\begin{array}{l}\text { Able to inspire and make employees feel comfortable to work in the } \\
\text { organization }\end{array}$ & $\checkmark$ & \\
\hline Written correctly, no bluffing & $\checkmark$ & \\
\hline Easy to be understood to all employees & $\checkmark$ & \\
\hline Focus on one ow two aspects & $\checkmark$ & \\
\hline The achievement can be measured & $\checkmark$ & \\
\hline Developed by CEO or top-level management not committee & $\checkmark$ & \\
\hline Validity is reviewed once a year & $\checkmark$ & \\
\hline $\begin{array}{l}\text { Realistic, explain the current organization and its own limited } \\
\text { resources }\end{array}$ & $\checkmark$ & \\
\hline Changeable, can be revised & $\checkmark$ & \\
\hline Easy to be remembered & $\checkmark$ & \\
\hline
\end{tabular}


Based on the existing criteria of good vision, the vision stated in the RPJMD Document of XYZ City Government meets all of the existing criteria.

TABLE 8: CRITERIA OF GOOD MISSION CHECKLIST

\begin{tabular}{|l|c|c|}
\hline \multicolumn{1}{|c|}{ Criteria } & Yes & No \\
\hline Clearly distinguish the organization and their competitor & $\checkmark$ & \\
\hline Define what the organization do and don' & $\checkmark$ & \\
\hline Identify the ability and key competences & $\checkmark$ & \\
\hline $\begin{array}{l}\text { Encourage the organization to make a better decision regarding the } \\
\text { future opportunities }\end{array}$ & $\checkmark$ & \\
\hline Clearly define the provided product or services & $\checkmark$ & \\
\hline No longer than one paragraph & $\checkmark$ & \\
\hline Easy to be understood & $\checkmark$ & \\
\hline Written in a good sentence without any meaningless word & $\checkmark$ & \\
\hline $\begin{array}{l}\text { Focus on current condition and don't combine it with a vision statement } \\
\text { for the future }\end{array}$ & $\checkmark$ & \\
\hline Can be reviewed and restated if the organization environment change & $\checkmark$ & \\
\hline Able to influence individual behavior specifically in organization & $\checkmark$ & \\
\hline $\begin{array}{l}\text { Reflect the organization competencies and refer to its strengths and } \\
\text { weaknesses }\end{array}$ & $\checkmark$ & \\
\hline Realistic and achievable & $\checkmark$ & \\
\hline Flexible to respond the environment change & $\checkmark$ & \\
\hline Refer to organization competitive advantage & $\checkmark$ & \\
\hline $\begin{array}{l}\text { Includes some logical statements value that encourage and facilitate the } \\
\text { communication inside and outside the organization }\end{array}$ & $\checkmark$ & $\checkmark$ \\
\hline
\end{tabular}

Based on the existing criteria of good mission, the mission stated in the RPJMD Document of XYZ City Government 2018-2023 meets all of the existing criteria.

Some strategies derived from the vision and mission stated in the 2018-2023 XYZ Government RPJMD document as in Table 9.

TABLE 9. STRATEGIES

\begin{tabular}{|c|c|}
\hline \multicolumn{2}{|c|}{ Strategies } \\
\hline Strengthen religious institutions & Improving the basic services of the poor population \\
\hline Increasing religious values and Pancasila & $\begin{array}{l}\text { Improving infrastructure, roads, regional spatial } \\
\text { planning, and residential area }\end{array}$ \\
\hline $\begin{array}{l}\text { Improving the enforcement of Regional } \\
\text { Regulations and handling the violations }\end{array}$ & $\begin{array}{l}\text { Improve supervision, preparedness, prevention of } \\
\text { disaster and fire management }\end{array}$ \\
\hline Improve access to health services & $\begin{array}{l}\text { Improve the control of pollution of soil, water, air, } \\
\text { environmental damage, waste management }\end{array}$ \\
\hline $\begin{array}{l}\text { Increasing public awareness of healthy living } \\
\text { behaviors }\end{array}$ & Increase investment promotion and cooperation \\
\hline Improving the quality and equity of Health $\mathrm{HR}$ & $\begin{array}{l}\text { Improve IT-based of business licensing and } \\
\text { investment sectors }\end{array}$ \\
\hline Improving the quality and equity of Education & $\begin{array}{l}\text { Improving the quality of cooperatives, MSMEs, } \\
\text { creative economy, tourism, and culinary }\end{array}$ \\
\hline Improving youth coaching and empowerment & Improve the quality of the trade sector \\
\hline $\begin{array}{l}\text { Improving the quality and quantity of achievement } \\
\text { and community participation in sports }\end{array}$ & $\begin{array}{l}\text { Improving quality food and protecting agricultural } \\
\text { land }\end{array}$ \\
\hline $\begin{array}{l}\text { Improve the quality of life and protection of } \\
\text { women }\end{array}$ & $\begin{array}{l}\text { Improve the planning, controlling, evaluating, and } \\
\text { supervising Regional Development }\end{array}$ \\
\hline $\begin{array}{l}\text { Develop policies related to family security and } \\
\text { welfare }\end{array}$ & $\begin{array}{l}\text { Improving quality, transparent, and accountable IT- } \\
\text { based Regional Financial Management }\end{array}$ \\
\hline $\begin{array}{l}\text { Program optimization related to family security } \\
\text { and welfare }\end{array}$ & $\begin{array}{l}\text { Improve management of the Regional Apparatus of } \\
\text { Sukabumi Government }\end{array}$ \\
\hline Develop policies related to population growth & $\begin{array}{l}\text { Improve Sistem Akuntabilitas Kinerja Instansi } \\
\text { Pemerintah (SAKIP) }\end{array}$ \\
\hline Compile policies related to labor & $\begin{array}{l}\text { Improve the evaluation and guidance of the } \\
\text { performance of the Regional Apparatus of } \\
\text { Sukabumi Government }\end{array}$ \\
\hline $\begin{array}{l}\text { Improve the quality and productivity of the } \\
\text { workforce }\end{array}$ & $\begin{array}{l}\text { Improve the quality of public services that have } \\
\text { Standard Operational Procedure (SOP) }\end{array}$ \\
\hline Increase job opportunities & $\begin{array}{l}\text { Optimizing the use of IT in the Regional Apparatus } \\
\text { of Sukabumi Government }\end{array}$ \\
\hline & $\begin{array}{l}\text { Improve research, assessment, and facilities for the } \\
\text { development of Regional Innovation }\end{array}$ \\
\hline
\end{tabular}

From each of those 3 perspectives, there are performance indicators that are selected and adjusted based on the organization's vision, mission, and the strategies mentioned earlier. the indicators were obtained that were in line with each SKPD responsible. Below are various performance indicators in each perspective that describe in Table 10, 11, as follows.

The linkages of performance variables can help organizations in analyzing interconnected indicator paths or analyzing causes and sub-causes that occur by establishing main problems in terms of indicators.

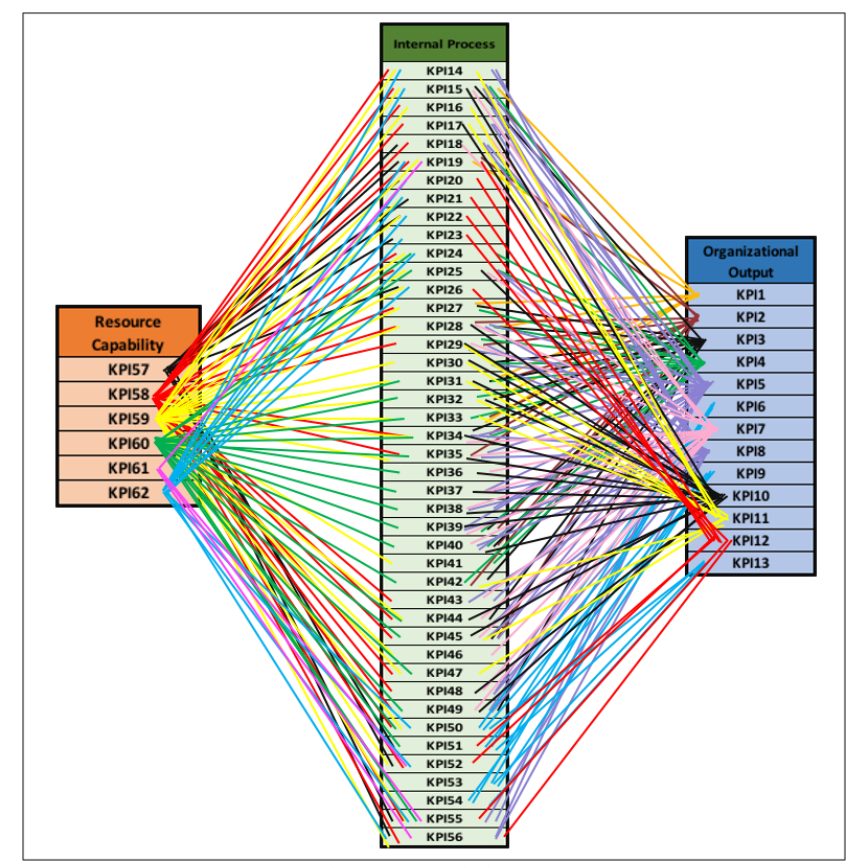

Fig. 4. KPI Linkages.

\section{Stage 3: Implementation}

\section{Current PMS}

XYZ Government implements a disintegrated Performance Management System, where the performance of the existing departments does not overlap with each other to achieve good performance towards the organization's vision and mission. The current situation of the PMS shows that the culture of employees is related to the change of the organization to be formed. It was demonstrated when the XYZ Government was run with limited understanding use of IT and communication even though this organization was already well-established in its financial condition.

This organization already applies PMS with indicators. But these indicators are not subdivided into real departments in XYZ Government.

\section{Reports for the New PMS}

Reports that must be supported by the new Performance Management System must be defined at the beginning of the design. The report specifications must be sorted out whether top-level management, middle, or employees at the operational level [5]. Each report for each level will differ indepth, detail, and period of time. 
TABLE 10: PERFORMANCE VARIABLES

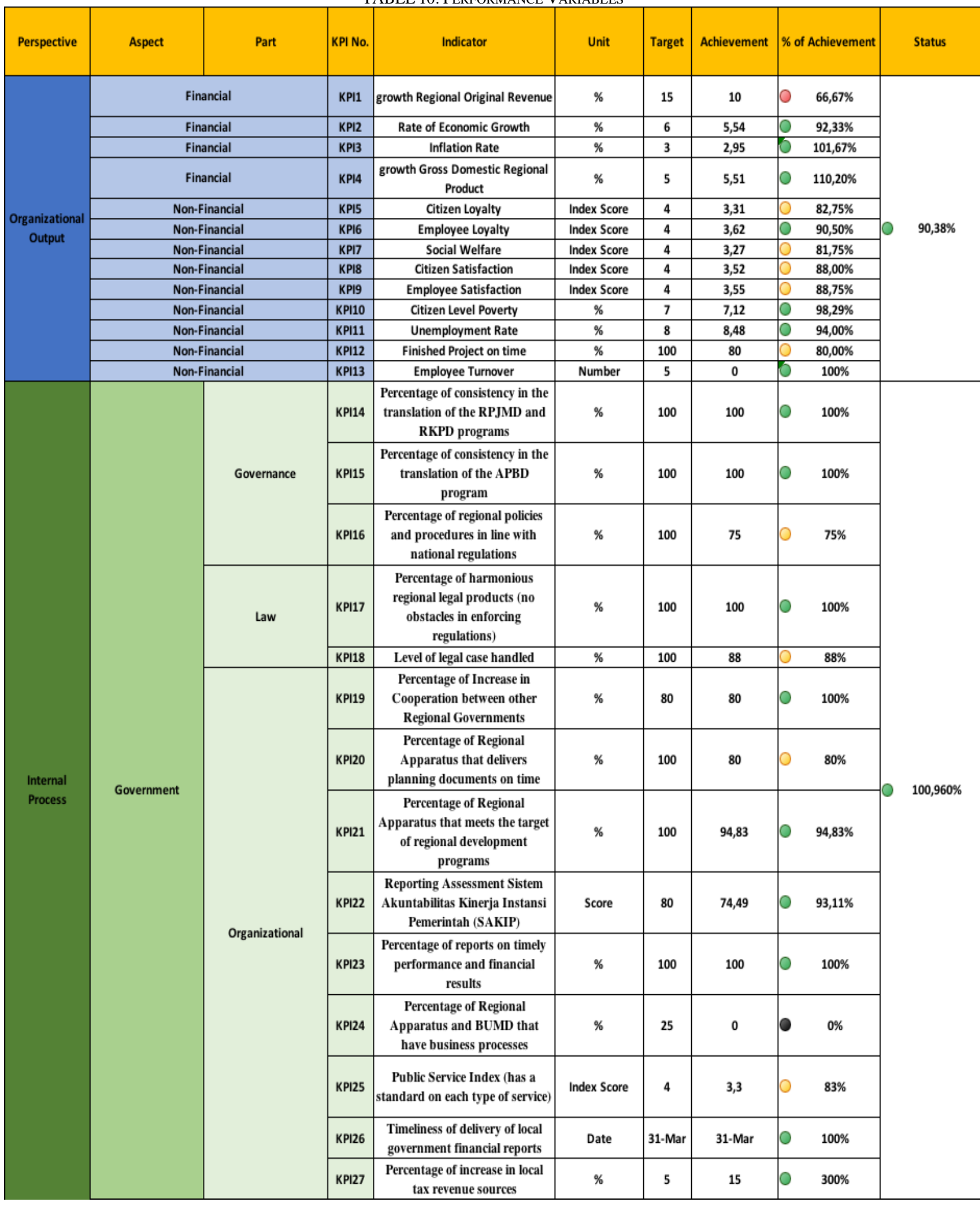


TABLE 11. PERFORMANCE VARIABLES (CONT.)

\begin{tabular}{|c|c|c|c|c|c|c|c|c|c|c|}
\hline \multirow{15}{*}{\multicolumn{2}{|c|}{$\begin{array}{l}\text { Economy \& } \\
\text { Development }\end{array}$}} & \multirow{6}{*}{$\begin{array}{c}\text { Economic } \\
\text { Administration }\end{array}$} & KPI28 & $\begin{array}{l}\text { Contribution of the trading } \\
\text { sector to GDP }\end{array}$ & $\%$ & 39,485 & 39,435 & o & $99,87 \%$ & \multirow{15}{*}{$91,61 \%$} \\
\hline & & & KP129 & Job Opportunity Level & $\%$ & 57,85 & 56,22 & 0 & $97,18 \%$ & \\
\hline & & & KP130 & \begin{tabular}{|c|} 
Percentage of young \\
entrepreneurs has just gained \\
capital
\end{tabular} & $\%$ & 70 & 54 & $\mathrm{o}$ & $77 \%$ & \\
\hline & & & KPI31 & \begin{tabular}{|l|} 
Percentage of Investor Growth \\
\end{tabular} & Number & 600 & 548 & 0 & $91,33 \%$ & \\
\hline & & & KP132 & Industrial growth & $\%$ & 3 & 1,58 & 0 & $52,67 \%$ & \\
\hline & & & KP133 & $\begin{array}{l}\text { Increasing culinary and } \\
\text { historical based tourism }\end{array}$ & $\%$ & 40 & 45 & o & $112,50 \%$ & \\
\hline & & \multirow{9}{*}{$\begin{array}{c}\text { Regional } \\
\text { Administration }\end{array}$} & KP134 & \begin{tabular}{|c|} 
Livable Cities Index \\
(Environmental Quality Aspects, \\
Public Transportation Aspects, \\
Facility Assessment Aspects, \\
Utility Assessment Aspects)
\end{tabular} & Index Score & 45 & 37 & 0 & $82 \%$ & \\
\hline & & & KP135 & \begin{tabular}{|c|} 
Environmental Quality Index \\
(Percentage of Improved River \\
Water Quality, Expansion of \\
Green Open Spaces in Urban \\
Areas (RTHKP), Percentage of \\
Waste Management) \\
\end{tabular} & Index Score & 42,83 & 42,67 & o & $100 \%$ & \\
\hline & & & KP136 & Percentage of Slums & $\%$ & 0,17 & 0,21 & 0 & $76,47 \%$ & \\
\hline & & & KP137 & $\begin{array}{l}\text { Percentage of population that } \\
\text { has access to drinking water }\end{array}$ & $\%$ & 68,77 & 68,17 & ○ & $99,13 \%$ & \\
\hline & & & KP138 & \begin{tabular}{|l|} 
Percentage of homes to sanitize \\
\end{tabular} & $\%$ & 100 & 87,57 & 0 & $87,57 \%$ & \\
\hline & & & KP139 & $\begin{array}{l}\text { Percentage of road facility } \\
\text { availability }\end{array}$ & $\%$ & 100 & 100 & o & $100 \%$ & \\
\hline & & & KP140 & $\begin{array}{c}\text { Percentage of infrastructure and } \\
\text { spatial achievement }\end{array}$ & $\%$ & 90 & 90 & ○ & $100 \%$ & \\
\hline & & & KP141 & $\begin{array}{l}\text { Percentage of Disaster Risk } \\
\text { Reduction }\end{array}$ & $\%$ & 1,25 & 1 & 0 & $80 \%$ & \\
\hline & & & KP142 & Regional Innovation Index & $\%$ & 60 & 57 & 0 & $95 \%$ & \\
\hline \multirow[t]{7}{*}{\begin{tabular}{c|} 
Internal \\
Process (cont.)
\end{tabular}} & \multirow{7}{*}{$\begin{array}{c}\text { Economy \& } \\
\text { Development (cont.) }\end{array}$} & \multirow{7}{*}{$\begin{array}{c}\text { Community Welfare } \\
\text { Administration }\end{array}$} & KP143 & \begin{tabular}{|c|} 
Religious Harmony Index \\
(percentage of increase in \\
mosque worshipers, percentage \\
of increase in religious activities)
\end{tabular} & Index Score & 94,98 & 94,68 & o & $99,68 \%$ & \multirow{7}{*}{$91,61 \%$} \\
\hline & & & KP144 & $\begin{array}{c}\text { Healthy Family Index (Maternal } \\
\text { Mortality Rate, Child Mortality } \\
\text { Rate, Management of infectious } \\
\text { and non-communicable diseases, } \\
\text { completeness of drug } \\
\text { availability, percentage of health } \\
\text { services according to the } \\
\text { standard) }\end{array}$ & Index Score & 0,207 & 0,177 & 0 & $85,51 \%$ & \\
\hline & & & KP145 & \begin{tabular}{|} 
Education Index (Average \\
number of years of schooling, \\
percentage of children not \\
attending school, percentage of \\
professional educators, \\
percentage of student \\
delinquency reduction, \\
percentage of reading interest \\
increase, number of cultural \\
diversity management) \\
\end{tabular} & Index Score & 69,81 & 69,8 & o & $99,99 \%$ & \\
\hline & & & KP146 & Life expectancy & Index Score & 72,05 & 72 & e & $99,93 \%$ & \\
\hline & & & KP147 & \begin{tabular}{|c|} 
Youth Development Index (won \\
provincial and national sporting \\
event medals, youth \\
entrepreneurship, percentage \\
increase in knowledge about \\
drugs) \\
\end{tabular} & Index Score & 9 & 8 & 0 & $88,89 \%$ & \\
\hline & & & KP148 & $\begin{array}{c}\text { Family Resilience Index } \\
\text { (percentage of well-off families; } \\
\text { percentage of homeless, elderly, } \\
\text { disability, neglected children } \\
\text { outside institutions receiving } \\
\text { social rehabilitation; percentage } \\
\text { of low-income families handled) }\end{array}$ & Index Score & 67,81 & 67,76 & o & $99,93 \%$ & \\
\hline & & & KP149 & Percentage of Food Safety & $\%$ & 86 & 78 & 0 & $90,70 \%$ & \\
\hline \multirow{7}{*}{$\begin{array}{c}\text { Internal } \\
\text { Process (cont.) }\end{array}$} & \multirow{7}{*}{ Administration } & \multirow{3}{*}{ General \& Protocol } & KPI50 & $\begin{array}{c}\text { Regional Secretariat Security } \\
\text { Index (protocol and security } \\
\text { services for each activity/events } \\
\text { of the Regional Secretariat) } \\
\text { according to Standard } \\
\text { Operating Procedure }\end{array}$ & Index Score & 4 & 3,66 & o & $91,50 \%$ & \multirow{7}{*}{$88,29 \%$} \\
\hline & & & KPI51 & $\begin{array}{c}\text { Complete information and } \\
\text { documentation for all events and } \\
\text { ceremonies of Regional } \\
\text { Secretariat } \\
\end{array}$ & Index Score & 4 & 3,46 & o & $86,50 \%$ & \\
\hline & & & KPI52 & $\begin{array}{l}\text { The level of achievement and } \\
\text { success of the planned work } \\
\text { program }\end{array}$ & Index Score & 4 & 3,48 & 0 & $87,00 \%$ & \\
\hline & & \multirow{3}{*}{$\begin{array}{c}\text { Equipment of Regional } \\
\text { Secretariat }\end{array}$} & KP153 & \begin{tabular}{|c|}
$\begin{array}{c}\text { The quality of vehicles, official } \\
\text { office housing needs, telephone, } \\
\text { water, etc. }\end{array}$ \\
\end{tabular} & Index Score & 4 & 3,59 & o & $89,75 \%$ & \\
\hline & & & KPI54 & $\begin{array}{l}\text { Level of fulfillment of household } \\
\text { services for Mayor, Deputy } \\
\text { Mayor, and the apparatus }\end{array}$ & Index Score & 4 & 3,61 & o & $90,25 \%$ & \\
\hline & & & KPI55 & $\begin{array}{c}\text { The level of effectiveness in the } \\
\text { management of regional } \\
\text { government organizations }\end{array}$ & Index Score & 4 & 3,45 & o & $86,25 \%$ & \\
\hline & & $\begin{array}{l}\text { Finance \& Staffing of } \\
\text { Regionak Secretariat }\end{array}$ & KPI56 & $\begin{array}{l}\text { The level of discipline of the } \\
\text { regional secretariat apparatus }\end{array}$ & Index Score & 4 & 3,47 & o & $86,75 \%$ & \\
\hline \multirow{5}{*}{$\begin{array}{c}\text { Resource } \\
\text { Availability }\end{array}$} & \multirow{3}{*}{\multicolumn{2}{|c|}{ Human Resource Capability }} & KP157 & Employee Productivity & $\begin{array}{c}\text { Total } \\
\text { Absent/day }\end{array}$ & 20 & 5 & o & $75,00 \%$ & \multirow{5}{*}{$84,64 \%$} \\
\hline & & & KP158 & Skill and Competencies & Test Score & 85 & 87 & o & $102,35 \%$ & \\
\hline & & & KP159 & Training and Development & person & 50 & 44 & p & $88,00 \%$ & \\
\hline & \multirow{2}{*}{\multicolumn{2}{|c|}{$\begin{array}{l}\text { Technology Resource Capability } \\
\text { Organizational Resource Capability }\end{array}$}} & KP160 & Technology Development Trends & Index Score & 4 & 3,02 & 0 & $75,50 \%$ & \\
\hline & & & $\begin{array}{l}\text { KPI61 } \\
\text { KP162 }\end{array}$ & $\begin{array}{c}\text { Organization Culture } \\
\text { Leadership }\end{array}$ & $\begin{array}{l}\text { Index Score } \\
\text { Index Score }\end{array}$ & $\begin{array}{l}4 \\
4\end{array}$ & 3,22 & 0 & $\begin{array}{l}80,50 \% \\
86,50 \% \\
\end{array}$ & \\
\hline
\end{tabular}


TABLE 12: SUPPORTING REPORTS FOR NEW PMS

\begin{tabular}{|c|c|c|}
\hline Perspective & Document Name & Person in Charge \\
\hline \multirow{8}{*}{$\begin{array}{l}\text { Organizational } \\
\text { Output }\end{array}$} & Regional Original Revenue & Economy \& Development \\
\hline & Rate of Economic Growth & Economy \& Development \\
\hline & Inflation Rate (monthly) & Economy \& Development \\
\hline & Gross Domestic Regional Product & Economy \& Development \\
\hline & Customer Satisfaction Survey Document & $\begin{array}{c}\text { Government, Economy \& } \\
\text { Development }\end{array}$ \\
\hline & Employee Satisfaction Survey Document & Administration \\
\hline & Statistics of Citizen Level Poverty & Economy \& Development \\
\hline & Statistics of Unemployment Rate & Economy \& Development \\
\hline \multirow{24}{*}{$\begin{array}{l}\text { Internal } \\
\text { Process }\end{array}$} & RPJMD and RKPD & Government \\
\hline & APBD & $\begin{array}{c}\text { Government, Economy \& } \\
\text { Development }\end{array}$ \\
\hline & Local Regulation and National Regulation & Government \\
\hline & $\begin{array}{c}\text { Regional Legal Products (Regional Regulations, Regulations } \\
\text { of DPRD and in the form of decisions include Decisions of } \\
\text { Regional Heads) }\end{array}$ & Government \\
\hline & Document of legal case & Government \\
\hline & Work Program Mayor \& Deputy & Government \\
\hline & Laporan Akuntabilitas Kinerja Instansi Pemerintah (LAKIP) & Government \\
\hline & BUMD Document & Government \\
\hline & Financial Reports & $\begin{array}{c}\text { Government, Economy \& } \\
\text { Development } \\
\end{array}$ \\
\hline & Survey Results of Community Satisfaction on Public Services & Government \\
\hline & Local Tax & $\begin{array}{c}\text { Government, Economy \& } \\
\text { Development } \\
\end{array}$ \\
\hline & GDP Contribution of all sectors & Economy \& Development \\
\hline & Investor Growth & Economy \& Development \\
\hline & Industrial Growth & Economy \& Development \\
\hline & Recapitulation Results of Livable Cities Index Measurement & Economy \& Development \\
\hline & $\begin{array}{l}\text { Recapitulation Results of Environmental Quality Index } \\
\text { Measurement }\end{array}$ & Economy \& Development \\
\hline & Recapitulation Results of Regional Innovation Measurement & Economy \& Development \\
\hline & $\begin{array}{c}\text { Recapitulation Results of Religious Harmony Index } \\
\text { Measurement }\end{array}$ & Economy \& Development \\
\hline & Recapitulation Results of Healthy Family Index Measurement & Economy \& Development \\
\hline & Recapitulation Results of Education Index Measurement & Economy \& Development \\
\hline & $\begin{array}{c}\text { Recapitulation Results of Youth Development Index } \\
\text { Measurement }\end{array}$ & Economy \& Development \\
\hline & $\begin{array}{c}\text { Recapitulation Results of Family Resilience Index } \\
\text { Measurement }\end{array}$ & Economy \& Development \\
\hline & $\begin{array}{l}\text { Recapitulation Results of Environmental Quality Index } \\
\text { Measurement }\end{array}$ & Economy \& Development \\
\hline & $\begin{array}{c}\text { Recapitulation Results of Regional Secretary Security Index } \\
\text { Measurement }\end{array}$ & Administration \\
\hline \multirow{6}{*}{$\begin{array}{l}\text { Resource } \\
\text { Availability }\end{array}$} & Employee Productivity Document & Administration \\
\hline & Performance Appraisal & Administration \\
\hline & Training Program Document & Administration \\
\hline & Technology Development Document & Administration \\
\hline & Culture Survey Document & Administration \\
\hline & Leadership Survey Document & Administration \\
\hline
\end{tabular}

\section{Socialization for the New PMS}

Socialization to implement a new system that is designed is crucial. Often, a Performance Management System that has been designed well enough by an organization will not be successfully implemented if it is not intensively socialized. The step of socialization is very vital because there is a large gap between top-level management and operational level management in terms of knowledge, long-term mindset, skills, and decision making. Therefore, organizational socialization must be designed in various alternative ways, such as poster design, leaflets, communication electronically connected (online system) morning meetings, routine meetings, and suggestion boxes. In every socialization process, each level must have a good understanding in terms of changes in the vision, mission, strategy, and work program of the organization.

\section{Analysis of Benefit to Cost Ratio}

Performing Analysis of BCR is needed to determine whether the newly proposed Performance Management
System to be implemented will provide significant benefits and advantages to the organization. For example, when an organization spend costs for training and certification in a department to improve the performance of an indicator. Or the cost of adding technology tools in the department to increase employee productivity. Another example is the cost of procuring facilities that can increase employee loyalty and satisfaction.

In addition, an Analysis of BCR must also be conducted for all alternative improvement proposed to advance the performance of a work indicator. Weighting/ranking is necessary to set priorities which performance indicators will take precedence for improvement and which provide significant benefits for the organization. BCR helps decisionmakers in organizations to compare various alternatives that should be preferred or rejected.

\section{Required Training}

Training and development are crucial that seeks continual growth and improvement for organization. It is a process of 
learning provided to new and existing employees to acquire knowledge, technical skills and developing attitudes of behavior in order to increase employee's productivity. Training and development is the organization's formal effort to improve the performance and self-fulfillment of their employees through educational programs and methods.

\section{Resource Allocation}

Resource allocation is closely related to the person who is responsible for each predetermined performance indicator. The person in charge is responsible for measuring, evaluating, diagnosing, and making decisions to follow up on gaps or decreases in the performance that occur. The resources allocated should be independent parties in order to be able to carry out objective evaluations and diagnoses without taking sides/support for the improvement process. The process of measurement, evaluation, and diagnosis is carried out with a computerized system and integrated with other performance indicators. This was done to shorten the time and simplify the process.

\section{Display}

The display is used to publish a number of information and data on the results of performance measurement and evaluation to the public at an internal level, especially information that is used as a summary of the performance of individuals, teams, or a department in an organization which will eventually be used as a self-motivation and creates a supportive work environment to one another. Each individual, team, or department will know each other's position on the overall performance of the organization through the display.

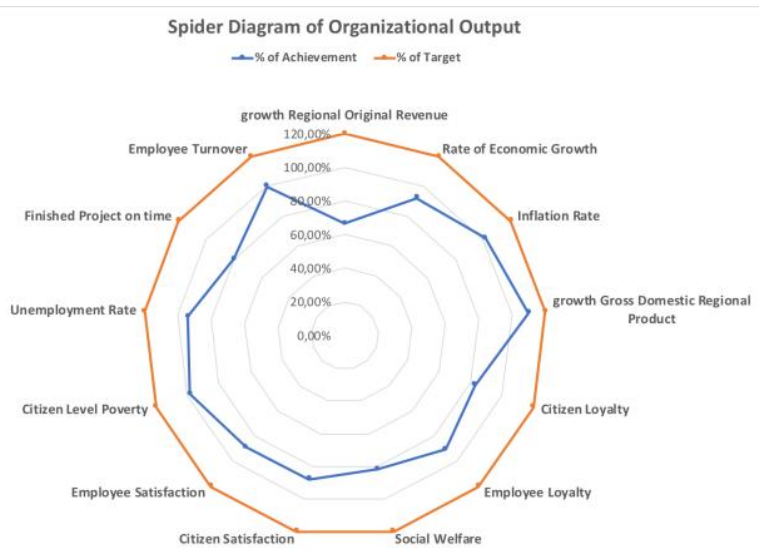

Fig. 5. Spider Diagram of Organizational Output.

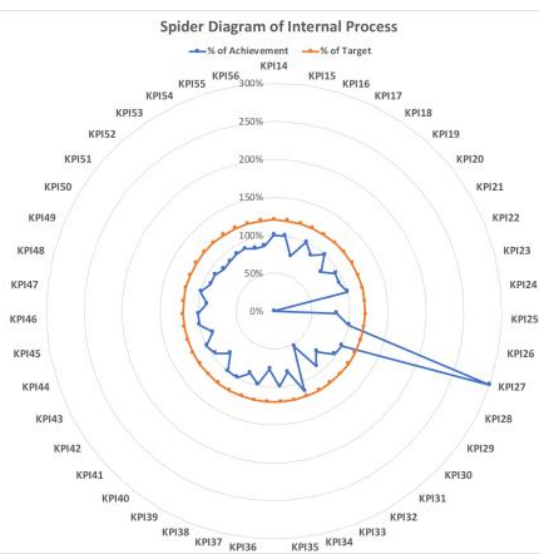

Fig. 6. Spider Diagram of Internal Process.

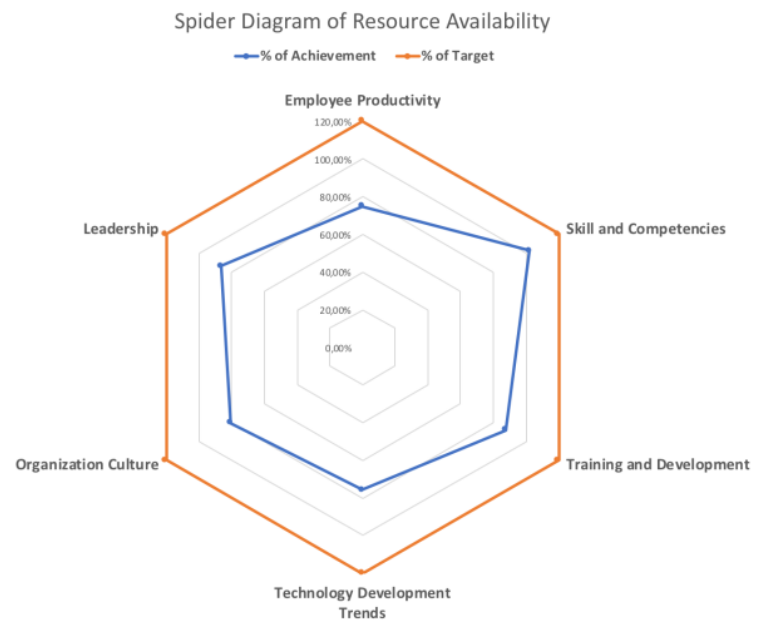

Fig. 7. Spider Diagram of Resource Availability.

\section{Testing of Proposed PMS}

Before implementing the newly designed Performance Management System, testing needs to be done to determine whether the proposed PMS is suitable and in accordance with the internal and external situation of the organization/not. Several stages must be done, i.e Performance Measurement, Evaluation of Measurement Result, Diagnosis of Alternative Improvement, and Follow Up.

\section{Performance Measurement}

Performance measurements have basically been implemented in almost all companies. However, this is often done only as a routine organizational activity without taking further action from the measurement results obtained. Measurement results provide real information, such as the gap between actual achievement and expected targets. Yet, there is no further information on why this could happen and alternative improvements that can be made. Therefore, performance measurement is the initial stage for further improvement analysis. The next step that is required is performance evaluation.

\section{Evaluation of Measurement Result}

Performance evaluation is a comparison between actual achievement with plans or standards that have been agreed upon in the beginning. Before performance measurements are carried out, the organization must set standards or best practices as targets or comparative studies (both internal and external).

Internal appraisal review can be done by looking at the best performance of the organization achieved, average past performance in a certain period, and others. In contrast, the external appraisal review can be done by comparing direct competitors, best practices in the same industry, and the average achievement of similar industries. Both appraisal review must be carried out together.

\section{Diagnosis of Alternative Improvement}

Performance diagnosis is a process that is carried out to get the cause of the deviation or performance gap that occurs between real achievement and the target set. The organization must find an exact cause that can explain the deviation of performance. Organizations can also use a qualitative approach by using accurate data that occurs in the field. Therefore, it is crucial to present a cause-effect diagram of each performance indicator used by using factor analysis, correlation analysis, Analytical Hierarchy Process, and 
various other approaches. The final results of the diagnosis can be in the form of several alternative improvements that can be executed to make the performance indicators keep on the track to achieve predetermined targets.

\section{Follow Up}

There are two different aspects that are taken in the follow up stage, such as technical aspects and strategic aspects. Technical aspects are usually in the form of improvements that focus on the short term. While the strategic aspect is an improvement that is more directed towards decision making at the top management level for the long term, for example, the improvement aspect of improving workforce qualifications by conducting training and development of employees according to organizational needs, increasing the qualifications will lead to organizational competition with the same industry. However, recruiting human resources and conducting training will have a large impact on company costs. So, the organization needs to make trade-offs to reconsider alternatives that can be prioritized to be executed in taking strategic actions.

\section{E. Stage 4: Maintenance and Update}

The Proposed Performance Management System that is designed must be dynamic and always updated to new developments related to changes in the competitive environment, regulations, stakeholder expectations, community needs, technology development, the achievement of performance standards, and the latest methods of performance management systems.

The other things need to be maintained for sustainability, such as leadership, commitment between individuals, the involvement of stakeholders both internal and external, and others to motivate organizations to do the best [5]. Below are the important things that must remain reviewed and updated, as follows:

1. Inspirational and transformational leadership.

2. Commitments that apply to all levels of the organization.

3. Involvement of all stakeholders.

4. Communication that occurs effectively in measuring, evaluating, diagnosing, and following up the PMS.

5. Feedback from all parties needed to assess what happened.

6. Availability of resources.

7. Learning and growth that occur must always be under the technological developments.

8. Environmental scanning is carried out both internally and externally to identify opportunities and challenges.

9. A sense of purpose, all activities are undertaken must remain focused on the goal/purpose.

10. Focus on the capacity of the organization.

\section{RESULT AND RECOMMENDATION}

To make sure that the proposed of new PMS can provide a best solution to XYZ City Government, it can be compared from the before and after of the implementation of PMS using 4 Principles Guidance and 5 Rules Guidance
TABLE 13: BEFORE AND AFTER IMPLEMENTING PMS USING 4 PRINCIPLES GUIDANCE

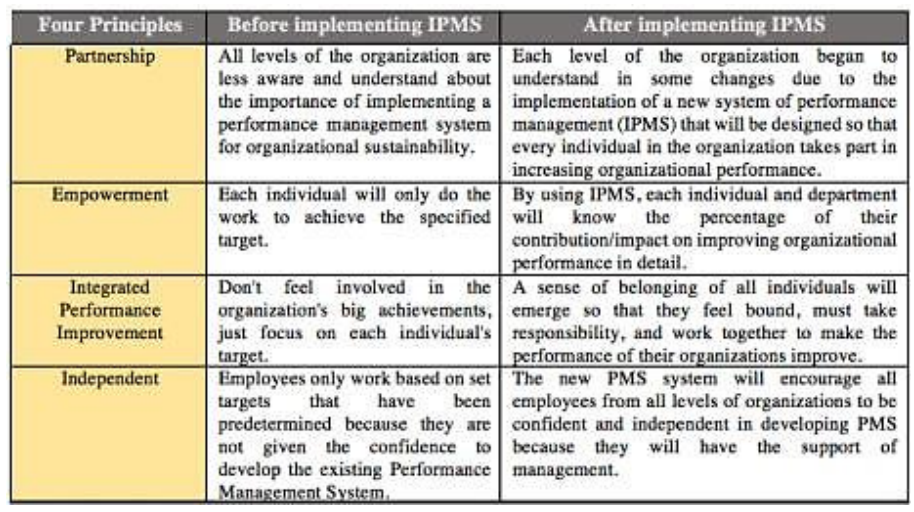

TABLE 14: BEFORE AND AFTER IMPLEMENTING PMS USING 5 RULES GUIDANCE

\begin{tabular}{|c|c|c|}
\hline Five Rules & Before implementing IPMS & After implementing IPMS \\
\hline $\begin{array}{l}\text { Keep It Stupid } \\
\text { Simple }\end{array}$ & $\begin{array}{l}\text { Performance indicators have been } \\
\text { designed by the organization but have } \\
\text { not been adjusted and are broken } \\
\text { down to departments/individuals who } \\
\text { must be responsible (unclear } \\
\text { responsibility) }\end{array}$ & $\begin{array}{l}\text { Performance indicators are broken down } \\
\text { based on departments and individuals. No } \\
\text { overlap of task/responsibility. }\end{array}$ \\
\hline Long-Term Oriented & $\begin{array}{l}\text { The orientation formed in the previous } \\
\text { PMS only focused on short-term, } \\
\text { cannot be modified according to } \\
\text { circumstances and needs of } \\
\text { organization, and only focuses on the } \\
\text { financial aspects. }\end{array}$ & $\begin{array}{l}\text { New IPMS that is applied will see the } \\
\text { organization's performance from the } \\
\text { helicopter view / all aspects that are mutually } \\
\text { integrated and long-term in view. }\end{array}$ \\
\hline Time Based & $\begin{array}{l}\text { Control over performance indicators } \\
\text { is not time based. }\end{array}$ & $\begin{array}{l}\text { IPMS will encourage ofganizations to } \\
\text { conduct performance control indicators over } \\
\text { time. Control will be carried out so that the } \\
\text { organization can know when specific } \\
\text { performance indicators show signs of } \\
\text { decreasing performance or uppoming failure } \\
\text { so that the organization will know what } \\
\text { corrective actions must be taken next. }\end{array}$ \\
\hline $\begin{array}{l}\text { Focus on Sustainable } \\
\text { Improvement }\end{array}$ & $\begin{array}{l}\text { Improvements ate made only fot the } \\
\text { current situation. }\end{array}$ & $\begin{array}{l}\text { The new IPMS system will record the } \\
\text { company's past performance to be used as an } \\
\text { internal benchmarking and external } \\
\text { benchmarking to other similar organizations. }\end{array}$ \\
\hline $\begin{array}{l}\text { Use Quantitative } \\
\text { Approach }\end{array}$ & $\begin{array}{l}\text { The previous PMS has used } \\
\text { quantitative variables (KPIs) by using } \\
\text { absolute numbers and ratios to } \\
\text { facilitate action taking and decision } \\
\text { making, but several indicaters are still } \\
\text { measured subjectively. }\end{array}$ & $\begin{array}{l}\text { In new IPMS, combination both quantitative } \\
\text { and qualitative targets will facilitate the } \\
\text { follow-up improvements. }\end{array}$ \\
\hline
\end{tabular}

\section{REFERENCES}

[1] Saragih, T. A., \& S. M. (2018). Analisis Perbedaan Kinerja Pemerintah Daerah yang dipimpin Kepala Daerah berlatar belakang Entrepreneur dan Non-Entrepreneur.

[2] Mardiasmo. (2006). Otonomi dan Manajemen Keuangan Daerah. Yogyakarta: Andi.

[3] Deb, T. (2008). Performance Appraisal and Management. New Delhi: Anurag Jain for Excel Books.

[4] Kaplan, R. S., \& Norton, D. P. (1996). The Balanced Scorecard. Harvard Business Review Press

[5] Wibisono, D. (2006). Manajemen Kinerja. Bandung: Erlangga.

[6] Hoskisson, R. E., Ireland, R. D., \& Hitt, M. (2016). Strategic Management: Concepts and Cases: Competitiveness and Globalization. Boston: Cengage Learning.

[7] Kotler, P., \& Keller, K. L. (2006). Marketing Management. Prentice Hall.

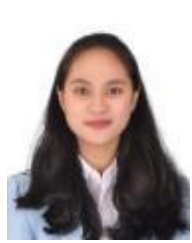

Ayu Regita Cahyani S. S.T., was graduated from Telkom University in 2018 majoring in Operation Project Management. She continued her study in Master of Business Administration at Bandung Institute of Technology. She took major in Operation and minor in Finance.

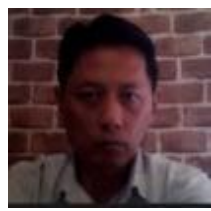

Muhammad Tresnadi Hikmat S.E., M.B.A, was graduated from Faculty of Economy in Universitas of Indonesia and Master of Business Administration, Bandung Institute of Technology. He took major in Operation. 